\title{
Thematic Structure in Barack Obama's Press Conference: A Systemic Functional Grammar Study
}

\author{
Heri Kuswoyo \\ Higher School of Foreign Language, Teknokrat College, Indonesia \\ E-mail: rikuyo_85@yahoo.com
}

Doi:10.7575/aiac.alls.v.7n.2p.257

URL: http://dx.doi.org/10.7575/aiac.alls.v.7n.2p.257
Received: 23/12/2015

Accepted: 10/02/2016

\begin{abstract}
This article looks into the theme - rheme pattern of presidential press conference that can be employed by speakers to organize the text in order to have a texture. Since a message should be conveyed in clause contextually and co-textually. Therefore, the objectives of this study are to analyze and describe the theme-rheme pattern employed in President Barack Obama's press conferences. The collected data are taken from Barack Obama's speeches in his press conferences on January $14^{\text {th }}$ and October $8^{\text {th }}$ 2013. The collected data are analyzed based on the theory of Systemic Functional Grammar put forward by Halliday. The method and technique used in this study are an analytic descriptive. This descriptive research finds (1) two kinds of theme-rheme pattern; namely; simple theme-rheme patterns and multiple theme-rheme patterns. The simple theme-rheme patterns contain constant theme pattern, linear theme or zigzag pattern, and derived theme-rheme pattern, and the multiple ones contain combination of constant theme and constant rheme, combination of constant and linear theme, combination of split and constant themes and another pattern is proposed by the researcher himself, namely derived rheme. The findings show that (2) the combination of constant and linear theme patterns is distributed most in both press conferences. In the contrary, combination of constant and split theme is only found once. To sum up, thematic structure can be used in developing of a text and making the message easily to be understood. Besides, it also can be used to have an effective communication to achieve specifiable goals.
\end{abstract}

Keywords: Thematic Structure, Press Conference, Systemic Functional Grammar

\section{Introduction}

As human beings, we always communicate. We use language as one of the devices to convey message that we want to share. Halliday (1994) states that language could be interpreted as a system of meaning. It means when people use language, their language acts to produce or construct meaning. Furthermore, Bloor \& Bloor (2004) argue that the ways in which people use language are classified into three; (1) language is used to organize, understand and express our perceptions of the world and of our consciousness. It is known as ideational meaning; (2) language is used to enable us to participate in communicative acts with other people, to take roles and to express and understand feelings, attitude and judgments. It is known as interpersonal meaning; (3) language is used to relate what is said (written) to the rest of the text and to other linguistic events. This involves the use of language to organize the text itself and to make language contextually and co-textually relevant. It is realized in lexico-grammar through thematic structure that is known as textual meaning. Thematic structure in English is the idea represented by the constituent at the starting point of the clause. In simple term, a clause begins with a realization of the theme. After that, it is followed by the realization of the rheme, which can be explained as being the rest of the message.

Table 1. Realizations of Theme and Rheme

\begin{tabular}{lc}
\hline $\mathrm{He}$ & is a smart boy \\
\hline Theme & Rheme \\
\hline
\end{tabular}

The example above shows that "He" refers to person that is talked about and "is a smart boy" as the rest of the clause. In addition, it talks about the theme (or it gives us more information about the theme).

According to the three systems of meaning above, the researcher is interested in discussing language function as textual meaning, especially the thematic structure in President's public activities that is Barack Obama's press conference. The reason why the researcher chooses the presidential press conference as the data source is because even there are many other researchers who have examined under a variety of labeling including, speech, campaign, debate, etc. Yet, it is very few studies that have explored presidential press conference. Fraser in Okulska and Cap (2010) also mentions that 
the framework of the presidential press conferences involves an aspect which is important to be analyzed since it is one of the most important vehicles by which presidents communicate to the media and public.

Regarding the issue, the researcher is interested in how the information is structured in English clause by President Barack Obama. Another point that makes the researcher is interested in discussing this issue is from the framework of presidential press conference itself because Soha (2003) mentions that Press conferences give the media direct access to the president and allow members of the mass media to ask specific questions and receive immediate responses from the president. It means that the message that the president delivered will be conveyed to the society. Completely the president must organize the texts in his speeches well. In other words, he should think about how the mass media (reporters or journalists) can get his messages and their point easily.

To answer the phenomenon above, the researcher applies Systemic Functional Grammar approach. It is on the foundation of work by the social semiotic linguist, Halliday. He (1985) views language as a resource for making meaning. These grammars attempt to describe language in actual use and focus on texts and their contexts. It can be said that this approach is very important since it can describe and interpret language in actual use and make a meaning resource. In addition, this approach highlights a key aspect. That is "context of situation". Halliday (1989) in Consorte (1999) states that the context of situation consists of three components which serve to interpret the social context in which meanings are being exchanged: the field, the tenor, and the mode of discourse. The field refers to what is happening, the tenor to the participants involved in the action, their statuses and roles, whereas the mode of discourse refers to how the language is being used and functioning in the overall situation.

To conclude, this study becomes important since the researcher expects that this study will be useful not only to enhance speaking but also writing activities, So that the texture aspect of writing or speaking can be achieved by both the writer (or speaker) and reader (or listener). Based on that explanation, the present researcher takes "Thematic Structure in Barack Obama's Press Conference: A Systemic Functional Grammar Study as the title of this research.

\section{Previous Studies}

As the researcher read and comprehended, there are several studies that identified a number of thematic structure issues, such as Sade (2007) in Pakistan Journal of social sciences. In her article, she examined the thematic progression in Cristian tracts written in Nigeria. Meanwhile, the study showed that the simple linear and constant thematic progression patterns are prominent in this discourse. Another study proposed Pamungkas (2009) in his thesis, "Tema pada slogan Iklan Berbahasa Inggris di media Cetak". He investigated psychological subject as the theme and rheme of the slogan, and the meaning of slogans based on field, tenor, mode and the theme and rheme of the slogans. Then, the result showed that psychological subject always exists in a clause especially in slogan as the data of the research but not for logical and grammatical ones.

Also, Sari (2009) in her thesis entitle " theme in the english declarative Clause" explored the types of subjects functioning as theme in the english declarative clause. The study indicated that there were some kinds of subject fuctioning as theme. They were psychological subject, grammatical subject, and logical subject. Further, the position of theme in a declarative clause could be filled by the conflation or combination of these three subjects. Another piece of previous research was a thesis by linda (2012) entitled " Thematic Progression in Children Stories: A Systemic Functional Grammar Analysis". This study not only discussed the types of thematic progression found in children's story texts but also described how children's story texts described how children's story texts are structured as message from the perspective of thematic progression. The last piece of previous research was delivered by Sujatna (2013) in her article, "Thematic Progression of the sundanese Female Writers". This article has been published in International Journal of Language Learning and Applied Lingustic World, Volume 4 (4), December 2013; 382. This study showed that $27 \%$ the sundanese female writers use simple thematic progression and $73 \%$ use multiple thematic progressions. There are three typesbof simple thematic progression: linear theme (9\%), constant rheme (9\%), and constant theme $(9 \%)$. The multiple thematic progression have three different types; two element thematic progression $(36,50 \%)$, three element thematic progression (18,25\%), and four thematic progression (18,25\%).

Regarding all pieces of theprevious studies above, most of them have discussed the same issue that is thematic structure; yet this study differs from them. It is said so, since this study will not only discuss the theme-rheme pattern but also investigate the element of theme and their functions.

\section{Systemic Functional Grammar Approach}

There are many theories of language (grammar) such as traditional grammar, formal grammar, transformational grammar, functional grammar, etc., that we have already known. When they are used will be depended on our perspectives. As Gerot \& Wignell (1994: 4) stated that grammars are validated by their usefulness in describing and explaining the phenomenon called language. For example, traditional grammar divorced from meaning and use. And it focuses on the rules for producing the correct sentences. Besides, Deterding \& Poedjosoedarmo (2001:104) mention that it analyzes and describes well-formed English sentences. Moreover, Sujatna $(2013: 2)$ argued that this approach concerns on the form of grammatical structures and their relationship to one another rather than their meanings or their use in different contexts. Conversely, in this study, the researcher will apply Systemic Functional Grammar. From its perspective, grammar is as the resource of meaning and concerns with its use. Gerot \& Wignell (1994: 6) say, "Functional grammars view language as a resource for making meaning." These grammars attempt to describe language in actual use and so focus on texts and their contexts. Furthermore, they are not only concerned with structure but also with how those structures construct meaning. Along the same Bloor \& Bloor (2004:2) states that for SFL, a 
language is a system of meanings. In other words, when people use language, their language acts produce or more technically, construct meaning. Briefly, it can be described with two following examples:

(1) Time flies like an arrow

(2) Tim told of a tragic

Table 2. Analysis of clause based on traditional and formal grammar

\begin{tabular}{ccc}
\hline Time & flies & like an arrow \\
\hline Noun & Verb & Prepositional phrase \\
Tim & told & of a tragic case \\
\hline
\end{tabular}

Table 3. Analysis of clause based on functional grammar

\begin{tabular}{ccc}
\hline Time & flies & like an arrow \\
\hline Participant: & Process: & Circumstance: \\
Actor & Material & Manner \\
\hline Tim & told & of a tragic case \\
\hline Participant: & Process: & Circumstance: \\
Sayer & Process & Matter \\
\hline & & (Gerot \& Wignell, 1994:6)
\end{tabular}

These two examples above show how traditional or formal grammar and systemic functional grammar analyze a clause. Besides, Gerot \& Wignell (1994: 6) emphasize on functional grammar labels element of the clause in terms of the function each are playing in that clause rather than by word class. Halliday in Deterding \& Poedjosoedarmo (2011:106) looks at the clause as representing simultaneously three different types of meaning. These refer to experiential, interpersonal and textual meaning. Thus, the researcher applies this kind of approach since it can help and answer the problem formulations. Along this line, Eggins (1994:2) states that Systemic Functional Linguistic is an approach which helps linguists to analyze and explain how meanings are made in everyday linguistic interactions.

\subsection{Thematic Structure}

In the background of the study, the researcher has explained that he will only focus on the textual meaning which organizes the text itself. Regarding its function, Halliday (1994:37) states that textual meaning looks at how we structure information in English, what we put where and why. Furthermore, Deterding and Poedjosoedarmo (2001:106) point out that textual meaning is expressed by thematic structure (the identity of theme, what we are talking about, and rheme, what we are saying about it). In addition (Bloor \& Bloor, 2004) defines that thematic structure operates at the level of clause and all full clauses have thematic structure.

Also, Halliday (1994:37) stated that Prague school of linguists use the term 'Theme' as the label for this function. The theme is the element which serves as the point of departure of the message; it is that which the clause is concerned. The reminder of the message, the part in which the theme is developed, is called in Prague school terminology the rheme, for example:

Table 4. Theme-Rheme structure

\begin{tabular}{ll}
\hline (3) The duke & has given my aunt that teapot \\
(4) My aunt & has been given that teapot by the duke \\
(5) That teapot & the duke has given to my aunt \\
\hline Theme & Rheme \\
\hline
\end{tabular}

According to the example above, the theme can be identified as that element which comes in first position in the clause. Moreover, Bloor \& Bloor (2004:71) mention that theme in English is to think of it as the idea represented by the constituent at the starting point of the clause. Therefore, the duke, my aunt and that teapot are the theme of those clauses.

\subsection{Theme-Rheme Patterns}

Since a message should be conveyed in clause contextually and co-textually, a text should have a texture or the quality of being a text. As Bloor\& Bloor (2004:84) state that a stretch of language which is coherence and makes sense is said to have a texture. Thus, In order to reach that goal, the clause must tight each other as what Hasan mentions in Sujatna (2013)"Cohesive devices help a text hang together, or be cohesive, that means they contribute to what Hasan terms a text's unity of texture." Further, Theme-Rheme patterns or thematic progression can be called as schematic structure or method of development of a text. Hasan in Paltridge (2000:140) says, 
"The notions of theme and rheme are also employed in the examination of thematic progression, or method of development of a text. Thematic progression refers to the way in which the theme of a clause may pick up, or repeat, a meaning from a preceding theme or rheme."

By conducting this study, we will know what the Theme-Rheme patterns employed by President Barack Obama. Regarding their types, Deterding \& Poedjosoedarmo (2001) and Bloor and Bloor (2004) classify the Theme-Rheme patterns which occur in English texts into four. They are constant theme pattern, linear theme pattern (zig-zag pattern), split rheme pattern, and derived themes. These patterns can be explained in details, as follows:

\subsubsection{Constant Theme Pattern}

In this type, the topic for the paragraph is introduced as the theme of the first clause. The theme of one clause is shared as the theme of the clauses following it. This type also presents the reader with the given information acts as the themes throughout the clauses while rheme presents new information which is not further discussed in the following clauses. This pattern can be drawn as follows:

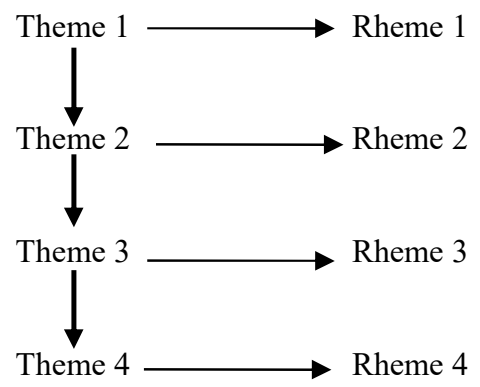

Figure 1. Constant Theme pattern

An example of a text which has such a structure is found below:

Noam Chomsky, author of Aspects of the Theory of syntax, revolutionized linguistics. He also happens to be well-known for his political views. In fact, he is better-known to laymen for his political views than he is for his revolutionary linguistic ideas (Deterding \& Poedjosoedarmo, 2001: 127)

The theme of the whole clauses of the passage above shares the same thing i.e. Noam Chomsky it is repeated by the pronoun "He" throughout the paragraph. In addition, the topic of every clause sometimes is found in the rheme, as Deterding \& Poedjosoedarmo (2001) states that this kind of pattern can occur in a text such as advertisement, like the following:

Everybody loves Boogie Burgers. Children love Boogie Burgers. Teenagers love Boogie Burgers. Parents love Boogie Burgers. Grandparents love Boogie Burgers.

A diagram of this structure is a follows:

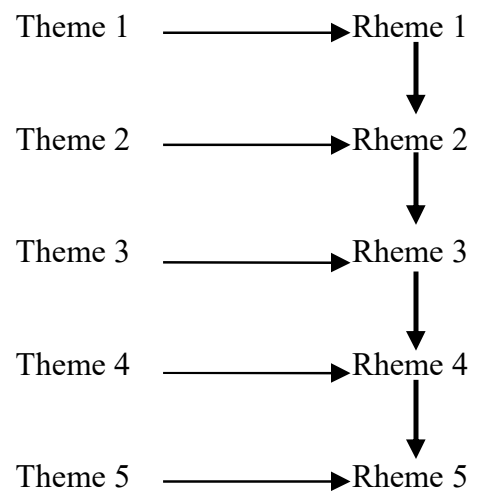

Figure 2. Constant Theme pattern

According to the text above, it indicates that it has same rheme throughout with different themes such as everybody, children, teenagers, parents, and grandparents. Besides, the topic of every clause can be found in rhemes. That is Boogie Burgers. Thus, this patten is called as constant rheme. 
The second type is linear theme pattern. In this type the idea introduced in the rheme of each clauses or the rheme becomes the theme of the next utterance. In another words, the rheme of one clause is taken up as the theme of the subsequent clause. In addition, Eggins (2004:324) called it as zig-zag pattern. She states that in this pattern, an element which is introduced in the rheme in clause 1 gets promoted to become the theme of clause 2 . This type of pattern It is represented graphically bellow:

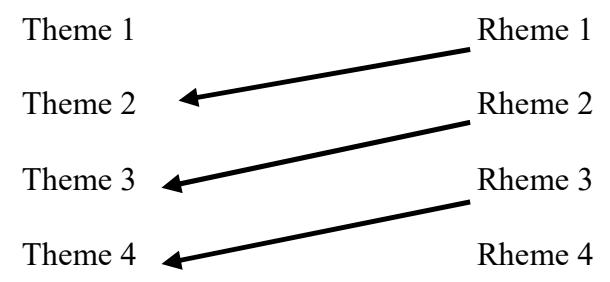

Figure 3. Linear Theme pattern

An example of this can be seen in the text bellow:

The museum is located in the centre of town near the square. This square is a common destination of tourist buses. The buses, all belonging to the island Tour Bus Company, are driven by the tour guides. These guides get off at each stop with the passengers and explain the sights to them. (Deterding \& Poedjosoedarmo, 2001: 128)

It explains that the theme element of the first utterance "the square" becomes the theme of subsequent utterance through the use of "this square". In this pattern, the thing presented as new information in the preceding clause becomes the given information in the subsequent clause which makes the subsequent clause always presents new information.

\subsubsection{Split Rheme Pattern}

In cases of complex text structure, the thematic patterns can be combined and manifested in the organization of the text. This type is a combination of both constant and linear patterns. It occurs when the rheme of a clause has two or more components, each of which is taken in turn as the theme of a subsequent clause. It can be represented in the pattern as follow:

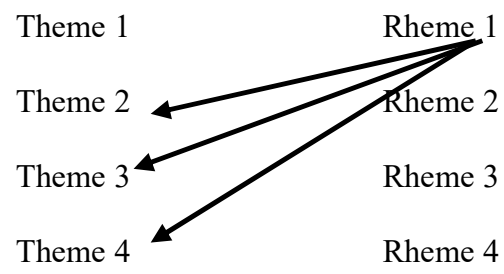

Figure 4. Split Rheme pattern

An example of split rheme can be seen bellow:

The fuels of the body are carbohydrates, fats, and proteins. These are taken in the diets......Carbohydrates are the principle source of energy in most diets....Fats make up the second largest source of energy in most diets....Proteins are essential for the growth and rebuilding of tissue. (Patpong, 2013:194)

According to the example above, the body fuels are composed of three sources of energy: carbohydrates, fats and proteins. Each of them is given thematic status one by one in subsequent clauses.

\subsubsection{Derive Themes}

Bloor and Bloor (2004: 91) mention that the term derived theme is used to describe expressions in the position of theme which are cohesively linked in meaning, but not necessarily in form, to a topic which has been stated earlier in the text. To sum up, the theme of a clause is not stated explicitly in the theme -rheme of the previous clause by the form, but it relates in meaning to the theme or rheme of the previous clause. It is represented graphically bellow:

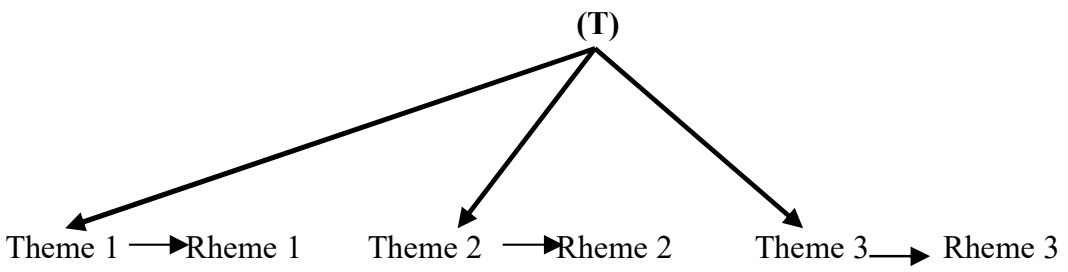

Figure 5. Derive Themes 
It represents an example of the derived progression below

New Jersey is flat along coast and southern portion; the northern-western region is mountainous.

The coastal climate is mild, but there is considerable cold mountain area during the winter months.

Summers are fairly hot..... (Sopyan, 2011:111)

The example above explains that each theme of the clauses is not mentioned explicitly in the Theme-Rheme of the previous clause. In addition, the themes are derived from a bigger part that is New Jersey which has its own characteristics, such as the climate, the season, etc. then, all characteristics are mentioned in the subsequent clauses. And the themes of the following clauses are related to the theme of their previous clause in meaning.

\section{Method}

Methodology is the main point of the research. As argued by Djajasudarma (2010:1),"kejelasan suatu penelitian dan keilmiahannya dapat dilihat dari metodologinya". It means that the research is categorized as scientific or it has a clear or sharp methodology. Thus, the researcher knows how to solve the research problem systematically. In addition, Perry (2005: 48) states that the methodology sections tell us about who studied, what was studied and how the information was collected and analyzed. Furthermore, Kothari (2004:8) adds that it is necessary for the researcher to know not only the research methods or techniques but also the methodology. Thus, the method of research should be concerned with two aspects; they are the method and technique of data collecting and the method and technique of data analysis.

4.1 The Method and Technique of Data Collecting

Perry (2005:52) says "this subsection explains in detail how the information is collected for the purpose of a research study". It means that in the collecting data, the researcher deals with the ways or procedures. The researcher uses several steps in collecting the data, namely: (1) downloading the video. In this step, the researcher downloades the video of President Barack Obama's Press Conference on January, 14 $14^{\text {th }} 2013$ and October, $8^{\text {th }} 2013$ through keepvid in http://keepvid.com/. (2) searching the transcript. In this step, the researcher looks for the transcript of the Barack Obama's utterances at his Press Conferences which were downloaded from www.politico.com and http://articles.washingtonpost.com. After that, (3) watching and listening the video while reading the transcript for the entire paragraphs Then (4) classifying the data based on the theories used and finally (5) drawing some conclusions based on the analysis.

\subsection{The Method and Technique of Data Analysis}

The method and study technique used in this study is analytic descriptive where the data taken are analyzed and then described based on the findings. According to Sudaryanto (1990:62), "istilah deskriptif itu menyarankan bahwa penelitian yang dilakukakan semata-mata hanya berdasarkan pada fakta yang ada atau fenomena yang memang secara empiris hidup pada penutur-penuturnya". Thus, in this study, the researcher aims to analyze and describe the phenomenon of thematic structure in Presidential press conferences by using Systemic Functional Grammar approach.

In addition, the researcher only analyzes two parts of the President Barack Obama's Press conference in 2013 that delivered on January $14^{\text {th }}$ and October $8^{\text {th }} 2013$. Totally, there are 57 Paragraphs. In details, the first press conference consists of 22 paragraphs and the second press conference consists of 35 paragraphs.

\subsection{Data Source}

The data are needed in conducting a research, since it is as the evidence of the research and the evidence will be convincing the accuracy of the result of the research (Perry, 2005). Then, the data analyzed in this study were taken from the video of President Barack Osama's speeches which have been transcribed into written texts. In addition, the speeches delivered at his press conferences on January $14^{\text {th }}$ and October $8^{\text {th }} 2013$ were downloaded from www.politico.com and http://articles.washingtonpost.com.

\section{Results and Discussion}

In this chapter, the research findings are presented according to the problem formulations. They are guided by three research questions regarding the theme-rheme patterns or thematic progression, the element of themes and their functions in Barack Obama's press conferences. This research is done in order to analyze the thematic choices made by a language user that can help to make a text coherent. It is considered as a significant part in language since it organizes the text as a message. Furthermore, the selected texts to be analyzed are taken from Barack Obama's press conferences that appeared on January, $14^{\text {th }}$ and October $8^{\text {th }} 2013$ and they are accessible on http://www.politico.com and http://articles.washingtonpost.com.

In addition, there are fifty seven (57) paraghraphs and three hundred and thirty eight (338) clauses taken as the data in this research. The first press conference consists of 121 clauses while the second one consists of 217 clauses. The findings are also based on the theory and the appropriate approach that has been applied, that is systemic functional grammar. The following sections deal with the detail explanation of the research conducted.

\subsection{Constant Theme Pattern}

This type of pattern identifies that the theme of one clause is shared as the theme of the clauses following it. It means that the theme of the whole clauses in a passage mentions the same thing and it is taken up from the theme of the previous clause. It can be illustrated in the following data: 
Data $1(36 / 21)$

We've got to create more jobs. We've got to boost the wages of those who have work. We've got to reach for energy independence. We've got to reform our immigration system. We've got to give our children the best education possible, and we've got to do everything we can to protect them from the horrors of gun violence.

(The text is adapted from News conference on the debt ceiling, fiscal battles and gun control, 2013)

The data (1) above shows that the theme in the subsequent clauses are taken from the theme of the previous clause that is $W e$, as it can be seen in the clause (108) In other words, this pattern focuses only on topic in the paragraph, for example the above paragraph is talking about $W e$ throughout the paragraph and it becomes the focus of paragraph. In details, the clause (108) establishes a theme $W e$ with the rest as rheme. Then the theme We of clause 109 remains the same theme until clause 113. It implies that Barack Obama as a speaker has tried to keep a text focused or cohesive by reiterating the element $\mathrm{We}$. The data of constant theme-rheme pattern also can be seen as follow:

Data 2 (37/20)

So let's finish this debate. Let's give our businesses and the world. The certainty that our economy and our reputation are still second to none. We pay our bills. We handle our business. And then we can move on - because America has a lot to do.

(The text is adapted from News conference on the debt ceiling, fiscal battles and gun control, 2013)

The data presented above also shows the constant theme pattern because the same themes are repeated at the beginning of successive sentences. In details, the theme of clause (101) let's is maintained in clause (102) as let's. Then the theme of clause (103) the certainty that our economy and our reputation refers to the previous clause let's; besides, the theme of clause (103) shares the same elements in clause (105), (106), and (107). In this data, although the theme in clause (106) is different; but all refer to the same topic $W e$. The third data sample can be illustrated as follow:

Data 3 (38/23)

Good afternoon, everybody. I am eager to take your questions, so I'll try to be brief at the top.

(The text is adapted from President Obama's News Conference on the shutdown and debt limit, 2013)

Based on the data (3) above, the paragraph consists of three clauses. Regarding the theory of systemic functional grammar, the clause (122) can not be analyzed since good afternoon is categorized as minor clause. In this case, the text can be called as constant theme pattern since the element of clause (123) does not change for the next clause. In other words, the speaker still keeps a text focused or cohesive by reiterating the element $I$. the next sample data can be seen as follows:

\section{Data 4 (39/2)}

I thought it might make sense to take some questions this week, as my first term comes to an end. It's been a busy and productive four years. And I expect the same for the next four years. I intend to carry out the agenda that I campaigned on — an agenda for new jobs, new opportunity, and new security for the middle class.

(The text is adapted from News conference on the debt ceiling, fiscal battles and gun control, 2013)

The theme of clause 3, I thought It, is shared in the clause 4 as as my first term. In another word, the word as my first term in clause 4 captures the intended meaning in clause 3 . But the different pattern is observed in the following clause, which is in the clause 5, clause 6 and clause 7. On the contrary, the topic moves constantly to their rheme. So this pattern is called as constant theme -rheme pattern.

\section{Data 5 (40/8)}

So we've made progress. We are moving towards our ultimate goal of getting to a $\$ 4$ trillion reduction. And there will be more deficit reduction when Congress decides what to do about the $\$ 1.2$ trillion in automatic spending cuts that have been pushed off until next month.

(The text is adapted from News conference on the debt ceiling, fiscal battles and gun control, 2013)

According to the explanation above, the part of clauses of the passage above shares the same theme which is $W e$. It can be seen in the clause 28 and 29. In the other hand, the topic of clauses also found in the rheme constatntly. It means that the pattern is began by constant theme and followed by constant rheme. Thus, it called as the theme-rheme pattern.

The following sub-sections deal with the element of ideational theme, interpersonal theme and textual theme and their functions within theme-rheme patterns in Barack Obama's press conferences.

5.2 Linear Theme-Rheme (zig-zag pattern)

The second type of theme-rheme pattern that used by Barack Obama in his press conferences is Linear theme-rheme or zig-zag pattern. As mentioned earlier, in this kinds of pattern, the rheme of one clause is taken up as the theme of the 
subsequent clause. In another words, an idea introduced in the rheme of each sentence becomes the theme of the following sentence. Further, this kinds of patterns found in both press conferences. The data can be seen in the following text.

\section{Data $6(41 / 34)$}

Except somewhere along the way, House Republicans decided. They wouldn't appoint people to the committee to try to negotiate, and 19 times they've rejected that. So even after all that, the Democrats in the Senate still passed a budget that effectively reflects Republican priorities at Republican budget levels just to keep the government open, and the House Republicans couldn't do that either

(The text is adapted from President Obama's News conference on the shutdown and debt limit, 2013)

Based on the data (6) above, the text can be categorized in the linear theme-rheme or zig-zag pattern since the element that is introduced in the rheme in clause 189 gets promoted to become the theme of clause 190. In this case, they, standing in place of house republicans. Then, the rheme of the third clause is taken up from the clause 190. Furthermore, the rheme portion of clause 192 (the democrats in the Senate still passed a budget that effectively reflects republican priorities at republican budget levels just to keep the government open) becomes the theme of the following sentence, that is (And the house republicans). Taking a look at the theme -rheme pattern, the text above can be called as linear theme-rheme or zig-zag pattern.

\section{Data $7(42 / 14)$}

These are bills that have already been racked up and we need to pay them. So while I'm willing to compromise and find common ground over how to reduce our deficits, America cannot afford another debate with this Congress about whether or not they should pay the bills they've already racked up. If congressional Republicans refuse to pay America's bills on time, Social Security checks and veterans' benefits will be delayed.

(The text is adapted from News conference on the debt ceiling, fiscal battles and gun control,2013)

In relation to data (7), this pattern indicates the theme and rheme come alternately. It shows that the theme-rheme pattern is linear theme-rheme or zig-zag pattern. It can be seen in the text above which consists of six clauses. In details, the data shows that the first theme becomes the second rheme and then, the second rheme becomes the third theme so the fourth theme becomes the fifth rheme. after that, the element that is introduced in the rheme in clause 64 gets promoted to become the theme of clause 65. It views that, refuse to pay America's bills on time, standing in place of Social Security checks and veterans' benefits.

Data 8 (43/57)

So with that, let me take a couple of questions. And I will start with Julie Pace of AP

(The text is adapted from President Obama's News conference on the shutdown and debt limit, 2013)

In accordance with the data (5) above, the text can be categorized in the linear theme-rheme or zig-zag pattern since the element that is introduced in the rheme in clause 337 gets promoted to become the theme of clause 338 . It means that let me, standing in place of and I. regarding the theme-rheme pattern above, it can be called as zig-zag pattern or linear theme-rheme.

\section{Data $9(44 / 3)$}

Right now, our economy is growing, and our businesses are creating new jobs, so we are poised for a good year if we make smart decisions and sound investments — and as long as Washington politics don't get in the way of America's progress.

(The text is adapted from News conference on the debt ceiling, fiscal battles and gun control, 2013)

Based on the data (9) above, the starting point is begun by linear theme -rheme then, moves to be constant. In details, the rheme of clause (8) our economy is growing becomes the theme of the immediately succeeding clause. Thus it called as linear theme pattern while the same themes are repeated constantly at the clause (9) to (13). So that it is called as constant theme. Here, the main topic of the text wholly $(\mathrm{We})$ even though the data shows that in the rheme of clause (8) and (10) are seen Our. According to the previous explanation, it can be concluded that in this paragraph can be called as the combination of linear theme-rheme and constant theme pattern. we shall now turn to another data.

Data 10 (45/10)

Now, I've said I'm open to making modest adjustments to programs like Medicare to protect them for future generations. I've also said that we need more revenue through tax reform by closing loopholes in our tax code for the wealthiest Americans. If we combine a balanced package of 
savings from spending on health care and revenues from closing loopholes, we can solve the deficit issue without sacrificing our investments in things like education that are going to help us grow.

(The text is adapted from News conference on the debt ceiling, fiscal battles and gun control, 2013)

In data (10) above, the paragraph consists of six clauses. Furthermore, the pattern is began by constant and followed by linear theme-rheme or zig-zag pattern. It is proven by the clause (35) which shares constantly to the following clauses. These are clause (36) and (37). It shows that the theme of clause (35) Now I keeps a text focused to the next theme of clause (36) $I$ and clause (37) I. It indicates that Barack Obama still keep the consistency of repetition as an effective way to create the cohesion. Then, the speaker tries to change the topic in clause (37). It shows that an element $I$ which is introduced in the rheme in clause (37) gets promoted to become the theme of clause (38), that is We. Thus, the linear pattern is identified. Next, the third data is explained.

\subsection{Combination of split rheme and Constant theme pattern}

The fourth type of theme-rheme pattern that is found in this research is the combination of split and constant themerheme. and this pattern is only found the second press conference. As it is pointed earlier, the split rheme pattern occurs when the rheme of a clause has two components, each of which is taken turn as the theme of subsequent clause. While in constant theme-rheme, the same theme is repeated at the beginning of successive sentences. The data can be seen in the following paragraph.

\section{Data 11 (49/49)}

And as I said, this one isn't even about deficits or spending or budgets. Our deficits are falling at the fastest pace in 60 years. The budget that the Senate passed is at republican spending levels. It's their budget that democrats were willing to put votes on just to make sure the government was open while negotiations took place for a longer-term budget.

(The text is adapted from President Obama's News conference on the shutdown and debt limit, 2013)

According to the data (8) above, clause (288) has two co-ordinated components in its rheme, indicated by the word both: (1) deficits or spending and (2) budgets. Further, the first, referring to deficits or spending, is taken up as theme of clause (289) our deficits. The second, referring to budgets, is taken up as ideational theme (thematic equative) of clause (290) the budget that the Senate passed. And the findings show that the constant theme-rheme pattern can be identified in clause (290) to clause (292). Here, the word the budget that the Senate passed is shared by the same theme in the following clause, which is it in clause (291) and continued to the clause (292).

5.4 Derived Theme

As it is pointed out earlier, this pattern is used to describe expressions in theme position which are cohesively linked in meaning, but not necessarily in form, to a topic which has been stated earlier in the text. In other words, each clause has different topic but they are derived from the same overriding theme or overall theme of a paragraph or text. In this research, the present writer finds four derived themes which exist only in the second press conference. The data can be seen as follows:

\section{Data $13(50 / 46)$}

Now, the good news is over the past $3 \frac{1}{2}$ years, our business have created $7 \frac{1}{2}$ million new jobs. Our housing market is healing; we've cut the deficit in half.

(President Obama's News conference on the shutdown and debt limit, 2013)

According to data above, the themes chosen by Barack Obama relate closely to the overall topic of clauses. Further, the subordinate themes in clause (270) our housing market and (271) we are derived from the hypertheme the good news. From this data, the speaker wants to tell us about the good news that they have had over the past $31 / 2$ years hence he describes the hypertheme the good news to the following clauses by linking cohesively in meaning our house market and $W e$ but they are not in form.

\section{Data $14(51 / 47)$}

Since I took office, the deficit is coming down faster than any time in the last 50 years. America is poised to become the number one energy producer in the world this year. This year, for the first time in a very long time, we're producing more oil than we're importing.

(President Obama's News conference on the shutdown and debt limit, 2013)

In relation to data 17 above, the themes chosen by Barack Obama also relate closely to the overall topic of clauses. Further, the subordinate themes in clause (273) the deficit (274) America and We are derived from the hypertheme I. From this data, Barack Obama wants to tell us about the good changes that he has done for America that relates to the deficit that has come down faster, America is poised to become the number one energy producer in the world and we or American people are producing more oil than importing. Therefore he describes the hypertheme $I$ to the following clauses by linking cohesively in meaning but they are not in form. 
In this pattern, the present writer finds the uncommon one that used by Barack Obama. It is called as derived rheme. Further, derived rheme differs from Bloor and Bloor's derived theme. As it pointed earlier, derived theme is a pattern where the topics of each clause are individually different, but all derived from the same overriding theme, or overall theme of a paragraph or text. In contrast, it is called as derived rheme since the subsequent sub-rhemes are derived from a superordinate item in Rheme position. The following texts are the samples of this pattern taken from the data.

\section{Conclusions and Suggestion}

\subsection{Conclusions}

According to the previous analysis, the researcher concludes some findings:

1. There are five kinds of theme-rheme or thematic progression found in Barack Obama's press conference on January $14^{\text {th }}$ and October $8^{\text {th }}$ 2013. They are constant theme pattern, linear theme or zig-zag pattern, combination of constant and linear theme, combination of split and constant themes and derived theme and

2. Another pattern is proposed by the researcher himself, namely derived rheme. Since it differs from Bloor and Bloor's derived theme. Derived theme is a pattern where the topics of each clause are individually different, but all derived from the same overriding theme, or overall theme of a paragraph or text. In contrast, it is called as derived rheme since the subsequent sub-rhemes are derived from a superordinate item in Rheme position.

3. Further, combination of constant and linear theme patterns are distributed most in both press conferences. While the combination between split theme and constant theme is only found in the second press conference.

4. Barack Obama uses all elements of ideational theme except predicator. These elements function to be marked theme, unmarked theme.

5. Barack Obama only uses one kind of element of interpersonal theme, that is modal adjunct ( $I$ though, ironically and even). And the function is to express the speaker's judgment regarding the content of the message.

6. The last, among three kinds of elements of textual theme, structural conjunction and continuative are found. In details, structural conjunction (and, so,) function to bind the clause and (when, if, while, since) function to link the clause. In addition, they signal the types of interdependent relation (enhancing and extending) while continuative (now) function to continue an idea or signal a new move is beginning.

6.2 Suggestion

The knowledge of theme -rheme pattern can be used by speakers to develop the message in their speeches. Not only a president who can applied it but also it can be used by a teacher, lecture, etc. it is said so since it can help the speaker to use well structured patterns to ensure the consistency and the coherence of their texts.

These types of analysis can be carried out in another spoken genre such as lectures, conversation, debate, speech etc. besides, it can be applied to another genre, for example autentic sources like magazine, newspaper, novel etc. the focus will be able to explore whether there is any corelation or not between perceive coherence and theme -rheme pattern or themtic progression.

\section{References}

Anderson, Ingela. (2005). American Political Rhetoric: Extended Essay. Lulea University of Technology Bloor, T. \& Bloor, M. (2004). The Functional Analysis of English (Second Edition). USA: Oxford University Press. Butt, D., Fahey, R.,Freez, S., Spinks, S. \& Yallop, C. (2000). Using Functional Grammar: An Explorer's Guide. Sidney, Australia: National Centre for English Language Teaching and Research, Macquarie University.

Consorte, C. (1999). Thematic Structure and Simultaneous Interpretation Some Experiental Evidence. "The interpreters's Newsletter", Pp. 99-124. Trieste: Edizioni Universita di Triste.

Deterding, D. \& Poedjosoedarmo, G. (2001). The Grammar of English. Singapore: Prentice Hall.

Djajasudarma, Fatimah T. (2010). Metode Linguistik: Ancangan Metode Penelitian dan Kajian. Bandung: PT. Refika Aditama.

Ebrahimi \& Khedri .(2012).The Importance of Thematic Structure in Student's Writing Cohesion. Language in India. Vol. 12: 64-78.

Eggins, Suzzane. (1994). An Introduction to Systemic Functional Linguistics. Great Britain: MPG books Ltd.

Gerot, L.\& Wignell, (1995). Making Sense of Functional Grammar. Sydney: Gerd Stabler.

Halliday, M.A.K. (1985). An Introduction to Functional Grammar. London: Edward Arnold.

Halliday, M.A.K. (1994). An Introduction to Functional Grammar: Second Edition. New York: Edward Arnold.

Halliday, M.A.K. \& Matthiessen, Christian M.I.M. (2004). An Introduction to Functional Grammar, 3rd Edition, London, Arnold.

Kothari, C.K. (2004). Research Methodology: Methods \& Techniques (Second Revised Edition). New Delhi: New Age International Publisher.

Kuypers, Jim A.(2009). Rhetorical Critisim. United Kingdom: Lexington Books Linda. (2012). Thematic Progression in Children Story: A Systemic Functional Grammar Analysis. Thesis; Unpublished. Bandung: Universitas Padjadjaran.

Lock, Graham. (1996). Functional English Grammar. New York: Cambridge University Press.

Maggie, L. (2007). Language and Politics: Use and Abuse of Language in Political Rhetoric. Dissertation. Hong Kong; University of Hong Kong. 
Martin, J.R., Matthiessen, Christian M.I.M., Painter, C., (1997). Working with Functional Grammar, London: Edward Arnold.

Okulska, U. \& Cap, P. (2010). Perspective in Politics and Discourse. USA: John Benjamin Publishing.

Paltridge, B. (2000). Making Sense of Discourse Analysis. Queensland: GerdStabler.

Pamungkas, Kasno .(2009). Tema pada Slogan Iklan berbahasa Inggris diMedia Cetak. Thesis; unpublished. Bandung; Universitas Padjadjaran.

Patpong, P. (2013). Thematic Progression of Thai Song Dam Folktales. Journal of the Southeast Asian Linguistics Society, $6,189-215$.

Perry, Fred L. (2005). Research in Applied Linguistics: Becoming a Discerning Consumer. New Jersey: Lawrence Erlbaum Associates Publishers.

Sade, O.C. (2007). Thematic Progression in Christian Written Discourse in Nigeria. Pakistan Journal of Social Sciences, 4(1) Pp. 64-68.

Sari, Puspita. (2009). Theme in the English Declarative Clause. Thesis; Unpublished. Bandung: Universitas Padjadjaran.

Soha, M.E. (2003). Presidential Press Conference Over Time. American Journal of Political Science, 47(2),348-353.

Sopyan, T. (2011). Thematic Progression in Indonesian Travel. Jurnal Ilmu Sastra, 6(1),100-129

Sudaryanto. (1990). Aneka Konsep Kedataan Lingual dalam Linguistik. Yogyakarta: Duta Wacana Press

Sujatna, E.T. (2013). Understanding Systemic Functional Linguistics. Bandung: Unpad Press.

Sujatna, E.T.(2013). Thematic Progression of The Sundanese Female Writers. International Journal of Language Learning and Applied Linguistics World, 4(4), 382-389.

Teich, Elke. (1999). Systemic Functional Grammar in Natural Language Generation. London: Cassel. 